\title{
Harmony Development of Graduation Project and Social Project Practice
}

\author{
Kui Dai
}

\author{
School of Civil Engineering and Architecture,Wuhan Polytechnic University,Wuhan,Hubei, China, \\ 430023,
}

Daikui888@163.com

Keywords: Graduation project; Teaching process; Project practice; Capacity

\begin{abstract}
Through graduation project teaching process analysis and summarizing, combine the graduation project and social project practice, explore a new teaching method, to how improve graduation project analyze and summarize, have pointed out the developing direction in the future of graduation project is the cultivation of the ability, the organic unifying of creating value practice and socialized development .
\end{abstract}

\section{Introduction}

Graduation design has the extremely vital significance in training students' comprehensive quality and engineering practice ability, and also the basic knowledge and professional knowledge than the comprehensive use of stage. Its purpose is to cultivate students' comprehensive learned the basic theories, basic knowledge and skills, analysis and the ability to solve practical problems; The basic training and complete engineer by scientific research method, the preliminary training initially established in the actual engineering design feeling design work, perceptual knowledge to environment, cultivate the atmosphere of mutual exchange and accumulate experience in the design of the ability. Graduation design can further develop the students' ability as follows: the ability to analysis, demonstration, calculation and design, apply computer and draw, compile technical documents and engaged in engineering design, construction, supervision and research scientific , etc.

\section{The Point and Complete of Graduation Design Teaching.}

There are many differences in graduate design content, form, dynamic change, actual relation and regular classroom. The specific performance in design, calculation, drawing, investigation and numerous frequent knowledge connections is also a kind of basic training, including theory and practice, which throughout the whole process of teaching[1]. These works should coordinated in areas as follows.

\section{The Guidance System in Teaching Organizations and the Standardization}

The department of graduation design teaching work should be established by the dean leadership team, the manager of department as the team leader, division the task clearly, individual responsibility, supervision and content institutionalization. Setting graduation design working according to professional structure engineering and project management for organization planning and researching, gradually spread below the graduation design teaching: formulating the work plan, organizing the teacher selecting research appropriate design topic, writing the graduation design specification and instructions.

Organizing the students to visit internship, collect and design material related, go to a lecture for difficult technical, computing explained drawing tools demonstration to let students understand the contents and requirements of graduation design.

Graduate work conference should be held regularly, summarizing the past work, for analyzing the problems existed.

Selecting a good example in the lecture to guide the design quality. 
Organization rejoin committee, made clear the graduation design quality assessment standards. The graduation design, the best by individual students write excellent defense in the application by the guide teacher agree, and in the public defense of organization, The special committee to organize a reply, for the students who failed to reply, or restarting the graduation design next year.

\section{The Contents and Requirements of the Graduation Design}

\section{Main Contents}

Students completed specified design topic independently under the guidance of the professional teachers, it should be ok for meeting school's graduation design guidance of the handbook requirements. A certain amount of documentation and graduation thesis should be included. (including calculations)

\section{Quality Level Degree}

Students can comprehensive application under the professional related subjects, mastering various graphics rendering software application. Drawing on quality shall be the quality standard of industry engineering design basis of evaluation, this paper should comply with quality industry engineering calculation quality standards and school related quality standards.

\section{Students' Ability and Comprehensive Qualities}

Through the graduation design, students should be able to do it: researching, collecting, inducting and analyzing materials according to subject requirements can properly use the relevant professional standard and reference book, having a good command of engineering design calculation method and procedure, making clear the corresponding engineering practice and the processing method, writing the chart with engineering requirements and technical documents, integrating engineering examples with theoretical analysis, combing with the construction drawing standards. Make students have the correct engineering design concept and the good team cooperation spirit, setting up the scientific attitude and serious acumen of work style.

\section{Topics ,Internships and Guiding Triangle Interaction Combination}

\section{Topic Selection Principle}

At first, it's should be targeted for the need of the society and the student's comprehensive knowledge structure in designing topics according to the development of science and technology. These does not conform to the time development of subject should be eliminated, advocating energetically in innovation which reflects the advanced technology development and has very strong social practice topic. Such as dragon building renovation project, involving concrete structure, foundation, steel structure, high-rise building structure , seismic design, CAD drawing, structure software calculation and construction, etc. Its innovation lies in using the steel structure and concrete materials will be new structure with original structure combined into a new buildings, the connection place must be ensure that can bear the corresponding internal force but also meet the stiffness and deformation requirement [2],to fit state and local norms in structural measures. At the same time the ultrasonic detecting should be found in the original structure for steel location and facilitate drill eye, making new structure reinforced and expansion bolts can enter into the original structure concrete, then to adopt binding, welding, casting technology, and guarantying lap length for anchorage [3], making two structures united into a just answer the whole. Its construction and construction technology is very exquisite which can cause student's strong interests, arouse their technical study ability, achieves a good learning effect, impressive knowledge and practice ability because of the technology available.

\section{The choice of base for practicing}

In the graduation design should organize students before graduation practice with a purpose, let them with problems, subject to practice, targeted action will have effect. Internship units should have a good construction technical level, have higher professional knowledge and experience and technical personnel, better organization management level. Make students have asked the answer, 
learning have comments, master technical knowledge have reliable points. Students to practice site should have more large-scale and high technology level of project, so that the students can learn the advanced engineering knowledge and technical knowledge and experience, get plenty of practical knowledge. To implement practice base, like the long-term immobilized students' practical base, which is conducive to practice as the accumulation of experience, important technology to the base's good environment, and cultivate talents, and more and more good atmosphere more solid ties with school, but also beneficial to the school of scientific and technological achievements pragmatism, marketization, form promote each other development incentive model. As a supplement and another kind of cultivating students' own way, should be encouraged to contact by teachers, internship site approved the practice mode strictly. This helps to arouse students' enthusiasm, exercise their social work ability, strengthen their active learning ability.

\section{Professional Teachers Guidance}

Graduation design practice teachers responsibility system, by the guide teacher lecturer, engineers and more titles personnel as. Teachers of both the best theoretical knowledge, and exquisite have abundant engineering design experience. To understand the student's psychology to motive base to mobilize students' motivation, arouse their interest [4]. Teachers must first understand the student's learning and knowledge structure, analysis of their capabilities, and summarized the classification, to determine different guidelines. Guidelines from the overall points are divided into two kinds, one kind is guiding teacher with a walk, one kind is guiding teacher follow. The former refers to the topic of students in teachers provisions, methods and steps, follow teachers, teachers sometimes step by step to decorate and explaining stages needed. This method allows students to avoid detours, quite smoothly finish design, design easy standardized form, graceful, drawing quality complies with the standards and evaluation result size easily grasp. But this method of favor the student to create consciousness, but for ability play poor students can yet be regarded as a kind of good method. The second approach is guiding teacher plays the role of supervision and correct direction, students according to the topic request, give full play to students' subjective initiative, each phase are the students themselves first. Finish, by the teacher inspection instruction. This method to the student independent creation and autonomous learning ability the raise good in the future, be helpful for their smooth to jobs. This requires ability of students. If guidance is not seasonable, student consumable large amount of time and energy invalid and easy to work efficiency is not high and frustration. And the third way is before two kinds of methods, both to make students mixed independently walk part way, meet difficulty, the key point, easy astray wrong place. Teachers must teach by beforehand, illuminate, enables the student to have the siler lining feeling, make impress them. This method also called to send one cheng, oneself walk again a ride. This method is suitable for the general students, the result is right.

\section{The Optimal Management of Graduation Design}

Graduation design involves knowledge in all courses is the most extensive, the design time is long, more than 14 weeks, process is complicated, student learning is tailored to the individual, takes care of the wide, involving more than a clue, must establish a set of effective graduation design, the quality management system.

\section{Preparation}

Should be established a set of powerful graduation design leadership team, to the whole of graduation design process related to make overall arrangement of graduation design, so as to facilitate the smoothly. Such as tutor arrangement, equipment classroom implement, students discipline management, problem solving mechanism formulation, the monitoring system, etc. 


\section{Graduate Design Detail Link Control}

\section{The teacher to quality assurance}

Teachers should ask students to graduate design idea, then analyze and solve their problems. In the student had certain the basis of preparation and conception, the teacher may the outline design method and fellowship territory about mind contents to make students have a clear concept and overall layout. Rest some key issues, especially points students focus and time to finish, already make students feel harvest very meaningful, and make the efficiency is greatly improved. For example, the type of hand count method to calculate the framework of internal force and reinforcement, illuminate can use structural mechanics torque distribution method, but more complicated, time-consuming method; If remind students use high-rise structure design of stratified torque distribution method (for under vertical load the approximate computation) and $\mathrm{D}$ value method and backhand points (under the horizontal load approximate calculation), can save time and energy, and accuracy completely meet the design requirements [5]. Students can realize the actual engineering method from the importance of their choice, close the distance with the future work.

\section{Out of the design process control}

Students in the design process, often encounter some difficulties, jam, Ken study students actively ask teachers or check information addressed, the student will fear stop, helpless. Not only wastes time and make progress suffocate suffocate, even endanger graduate design successfully completed. Extremely individual students and simply completely stopped working, waiting for reference other's answers. Teachers should promptly to solve problems, not only make students ability to solve problems get leap, still can make students' learning passion get high. For example in 15 layer high-rise structure design, students based on what basis with what kind of geological not well understood, based on complex how design more heart countless. Teachers should points out: shallow foundation bearing capacity is not high, can do for multilayer, natural foundation. Because of a high-rise, big, must use pile load. Foundation should adopt the pile raft foundation reinforcement, raft double bidirectional, and should demonstrate how to use PKPM calculation of internal force and raft reinforcement. The student to listen to, his knowledge all feel a new level, increased enthusiasm was also fully aroused.

\section{The graduation design and practice 4.2.3 cohesive}

When the design, students are required to use in practice the middle school to technology experience, make them master theory and practice method. E.g. housing space is not high, the span of small, then beam should be designed for flat beam, beam haunched to meet and local strength requirement. At the site seen drawings and field observed after construction, this method can be used to guide the students in the graduation design, and mechanics calculation and technical analysis. Make students understand that many of the actual engineering design methods and experience and knowledge principle is inseparable, so that they understand the importance of work hard in school.

\section{Conclusions}

Graduation design itself is equivalent to a system engineering, combined with social practice of constructing schools, is go out, please come in a platform for teaching. In this respect recent years we have done a lot of work and achieved encouraging results: students hubei province won many, the propaganda department, youth corps committee, WenMingBan social science, serves the citation practice activities, and achieved good social value. Graduation design has also repeatedly won the province of graduation design award outstanding. We will make the graduation design develop learning capability and the development of the social practice of an organic whole, make the students for the graduation design can create considerable economic value, and can give schools bring good social influence . 


\section{References}

[1] Ministry of Education, Division of Personnel Group with Higher Education (Revised Edition) Higher Education Press 1999237-238 page(in Chinese).

[2] Southeast University School Code of concrete structures (Second Edition) China Building Industry Press 2002208-210 page(in Chinese).

[3] Design of Beijing General Research Institute for Nonferrous Metals. Concrete Construction Manual. China Building Industry Press, 199446-49 pages(in Chinese).

[4] Ministry of Education, Higher Education Group with the Division of Personnel Psychology (Revised Edition) Higher Education Press, 2000. 3(in Chinese).

[5] Fang E Hua, Qian Jia Ru. High-rise building structure design. China Architecture Building Press, 2003.9 91-98 pages(in Chinese). 